Trakya Eğitim Dergisi

Cilt 10, Sayı 3

Eylül 2020, 980-994

Gelis Tarihi: 13.01.2020

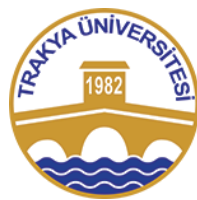

ISSN : 2630-6301

Doi:10.24315/tred.674462

Araştırma Makalesi

Research Article
Trakya Journal of Education

Volume 10, Issue 3

September 2020, 980-994

Yayına Kabul Tarihi:15.05.2020

\title{
Fen Bilgisi Öğretmen Adaylarının 3d Teknolojilerini Öğrenme Ve Uygulama Deneyimleri: Tinkercad Örneği
}

\section{Pre-Service Science Teachers' Learning and Implementation Experiences with 3d Technologies: The Example Of Tinkercad}

\begin{abstract}
Alev DOĞAN ${ }^{1}$, Gülşah ULUAY ${ }^{2}$
ÖZ: Bu araştırmanın amacı 3D tasarım programlarından biri olan Tinkercad Programının kullanımıyla ilgili fen bilgisi öğretmen adaylarına eğitim vermek ve adayların söz konusu programın fen derslerinde kullanımına yönelik görüşlerini belirlemektir. Bu amaç doğrultusunda, 2016-2017 bahar döneminde 7 hafta süren bir eğitim programı yürütülmüştür. Araştırmanın çalışma grubunu bir devlet üniversitesinin son sınıfinda öğrenim gören 40 fen bilgisi öğretmen adayı oluşturmaktadır. Araştırmanın deseni durum araştırması olarak belirlenmiştir. Nitel verilerden oluşan araştırmanın veri toplama araçları yarı yapılandırılırmıș görüşme formu ve öğretmen adaylarının hazırladıkları dokümanlardır. Görüşme süreci 3 adet açık uçlu sorudan oluşturulan yarıyapılandırılmış görüşme formu ile yürütülmüştür. Doküman hazırlama süreci ise Tinkercad programının fen derslerinde kullanımına yönelik görüşlerin açıklanmasıyla tamamlanmıștır. Veri analizi aşamasında, nitel analiz yöntemlerinden içerik analizi kullanılmıştır. Elde edilen verilerin analiz sonuçlarına göre, öğretmen adayları Tinkercad Programını kullanırken ve uygulama yaparken zorluk yaşamadıklarını belirtmiş ve programın fen derslerinde uygulanabilir olduğunu ifade etmişlerdir. Ayrıca, gelecekteki mesleki yaşantılarında kendi

ABSTRACT: The aim of this research is to provide training for pre-service science teachers about the use of Tinkercad Program which is one of the $3 \mathrm{D}$ design programs and to determine opinions of the pre-service teachers about the use of the program in science courses. For this purpose, a 7-week training program was conducted in spring term of 2016-2017. The study group consisted of 40 pre-service science teachers who were studying at the last year of a public university. The research design was determined as a case study. Data collection tools of this qualitative research were semi-structured interview form and documents prepared by preservice teachers. The interview process was conducted with a semi-structured interview form consisting of 3 open-ended questions. Preparing the document phase was completed by explaining the opinions about the use of Tinkercad program in science classes. In data analysis process, content analysis method that is one of the qualitative analysis methods was used. According to the results of the analysis, the pre-service teachers stated that they did not have any difficulties while they were using the Tinkercad and said that the software was applicable in science classes. They also determined that they would use the program in their classes in their future professional lives.
\end{abstract} sınıflarında programı kullanacaklarını da belirtmişlerdir.

Anahtar sözcükler: Tinkercad, 3D dijital uygulama, öğretmen adayı, fen ögretimi.
Keywords: Tinkercad, 3D digital implementation, pre-service teacher, science teaching

\section{Bu makaleye atıf vermek için:}

Doğan, A. ve Uluay, G. (2020). Fen bilgisi öğretmen adaylarının 3d teknolojilerini öğrenme ve uygulama deneyimleri: Tinkercad örneği. Trakya Ĕgitim Dergisi, 10(3), 980-994

\section{Cite this article as:}

Dogan, A. \& Uluay, G. (2020). Pre-service science teachers' learning and implementation experiences with 3d technologies: The example of Tinkercad. Trakya Journal of Education, 10(3), 980-994

\section{EXTENDED ABSTRACT}

\section{Introduction}

Nowadays, it is seen that a variety of instructional technologies and methods are used in classroom environments. Three-dimensional (3D) implementations has become popular among these instructional technologies (Smiar \& Mendez, 2016; McCollum, Regier, Leong, Simpson \& Sterner, 2014).

When studies on technology integration into science teaching are examined, the benefits of 3D implementations and their positive effects on students are emphasized in many studies (Schwarz, Reiser, Davis, Kenyon, Achér, Fortus, Shwartz, Hug \& Krajcik, 2009). 3D technology applications create a new environment for science teaching. The advantages of this new technology in chemistry, biology and physics are intensely important (Copolo \&Hounshell, 1995; Kaberman \& Dori, 2009; Zheng, Birktoft, Chen, Wang,

\footnotetext{
${ }^{1}$ Prof. Dr., Gazi Üniversitesi, Eğitim Fakültesi, doğan.alev@gmail.com, alevd@ gazi.edu.tr, ORCID ID: 0000-0002-8907-1344

${ }^{2}$ Dr. Öğr. Üyesi, Ordu Üniversitesi, Eğitim Fakültesi, gulsahuluay@ @mail.com, ORCID ID: 0000-0002-6365-5122
} 
Sha, Constantinou, Ginell, Mao \& Seeman, 2009; Yarema, Deptuch, Hoff, Shenai, Trimpl, Zimmerman, Demarteau, Lipton \& Christian, 2010; Yarema, Deptuch, Hoff, Shenai, Trimpl, Zimmerman, Demarteau, Lipton \& Christian, 2010; Stieff, Ryu, Dixon \& Hegarty, 2012; Stieff, Hegarty \& Deslongchamps, 2011; Lazarowitz \& Naim, 2013).

Especially during teaching process of some chemistry subjects within the scope of science subject matters, existing teaching techniques are developed by including the third dimension which is missing in the drawings (Perdomo, Shiratuddin, Thabet \& Ananth, 2005). For example, in a study conducted by Scalfani and Vaid (2014), various digital 3D structures of molecular structures were prepared. According to the results of the research, it was stated that it can be easier to teach symmetry and point groups with these structures. In another study carried out by McCollum, Regier, Leong, Simpson and Sterner (2014) with undergraduate students, 3D molecule structures were prepared by using iPad. According to the results obtained by the researchers, it was found that the students working with $3 \mathrm{D}$ molecule structures had higher conceptual competence than the students working with only worksheets. However, it is stated that these implementations are useful for teaching various subjects such as orbital and block copolymer nanostructures in different studies in literature (Lolur \& Dawes, 2014; Robertson \& Jorgensen, 2015; Scalfani, Turner, Rupar \& Jenkins, 2015).

From this point of view, the aim of this study is determined to introduce the Tinkercad program which provides $3 \mathrm{D}$ application to the pre-service science teachers, and to enable the pre-service teachers to make applications by using the program and to determine their views on the usability of the program in science courses.

\section{Method}

In this study, case study design which is one of the qualitative research methods was used. This research design is an approach that enables understanding of a case by using various data sources (Baxter \& Jack, 2008). The nature of this social case varies in case studies. For example, the case may be an institution, a role or role-playing, a city and a group of individuals (Feagin, Orum \& Sjoberg, 1991). In this study, a group of pre-service teachers constitutes the case of the study. In a case study, it is also important to examine the concept of the case and what the case is. The concept of case is defined as a phenomenon occurring in a limited content and is actually expressed as an element of analysis (Miles \& Huberman, 1994). In this context, the case of the study was determined to identify the pre-service teachers' views on Tinkercad program.

Participants of this study consists of 40 volunteer pre-service science teachers studying in the spring term of 2016-2017 academic year in the science education department of a public university. The data collection tools of the study were determined as documents prepared by pre-service teachers and semi-structured interview form. For data collection process of the research, a training program was designed in which Tinkercad program was introduced to pre-service teachers. The training program was completed in 7 weeks within the scope of a two-hour session each week. Throughout the design process, pre-service teachers worked in groups as collaborators. During the process, researchers assisted participants in using the program by providing feedback.

\section{Discussion and Conclusion}

As a result of the documents written by pre-service teachers, it was seen that the participants had generally positive opinions towards Tinkercad program. The pre-service teachers stated that Tinkercad program implementations are suitable for science teaching and also, they expressed that through the educational environments supported by Tinkercad the skills such as curiosity, creativity and imagination of the students will develop and thus, active participation in the classroom will be encouraged. Similarly, in the literature, researchers emphasize that such technologies will arouse interest and curiosity of students and improve their motivation (Cradler, J., McNabb, M., Freeman, M., \& Burchett, R. 2002).

The results of this research revealed that pre-service teachers should be provided with opportunities to have more experience in technology integration in their courses during their education processes and there is a need for new studies investigating how such implementations can be used in classroom environments. 


\section{Gíriş}

20. yüzyılın başından beri fen öğretiminde kullanılan öğretim yaklaşımları ve kullanılan öğretim teknikleri sürekli değişip gelişmektedir (Noeth \& Volkov, 2004). Bu değişimin nedeni öğretim teknolojileri ile desteklenen bir eğitsel sürecin geleneksel yöntemlerden uzaklaşarak yapılandırmacı yönteme dönüşmesi ve bu sayede öğrenci merkezli öğrenmelerinin öneminin de artması şeklinde ifade edilebilir (Matzen \& Edmunds, 2007). Bununla birlikte, yeni nesillerin yeni teknolojilere hazır olmaları (Han, Eom \& Shin, 2013) da dikkate alındığında, geleceğin öğretmenlerini yetiştiren öğretmen eğitim kurumlarının en önemli hedefleri arasında öğretmen adaylarının teknoloji entegrasyonunu etkili bir şekilde gerçekleştirebilmelerinin sağlanması yer almaktadır (Drummond \& Sweeney, 2017). Bu nedenle, günümüzde sınıf ortamlarında çok çeşitli öğretim teknolojileri ve yöntemlerinin kullanıldığı görülmektedir. Söz konusu öğretim teknolojileri arasında özellikle üç boyutlu (3D) uygulamalarla öğretim de popüler hale gelmiştir (Smiar \& Mendez, 2016; McCollum, Regier, Leong, Simpson \& Sterner, 2014).

Teknolojinin fen öğretimine entegre edilmesi üzerine yapılan çalışmalar incelendiğinde, birçok araştırmada 3D uygulamaların faydaları ve öğrenciler üzerindeki pozitif etkileri vurgulanmaktadır (Schwarz, Reiser, Davis, Kenyon, Achér, Fortus, Shwartz, Hug \& Krajcik, 2009). 3D teknolojisi uygulamaları fen öğretimi için yeni bir ortam oluşturmaktadır. Bu yeni teknolojinin kimya, biyoloji ve fizik alanlarına sunmuş olduğu avantajlar son derece önemlidir (Copolo \&Hounshell, 1995; Kaberman \& Dori, 2009; Zheng, Birktoft, Chen, Wang, Sha, Constantinou, Ginell, Mao \& Seeman, 2009; Yarema, Deptuch, Hoff, Shenai, Trimpl, Zimmerman, Demarteau, Lipton \& Christian, 2010; Yarema, Deptuch, Hoff, Shenai, Trimpl, Zimmerman, Demarteau, Lipton \& Christian, 2010; Stieff, Ryu, Dixon \& Hegarty, 2012; Stieff, Hegarty \& Deslongchamps, 2011; Lazarowitz \& Naim, 2013).

Özellikle fen bilimleri kapsamındaki bazı kimya konularının öğretiminde, çizimlerde eksik olan üçüncü boyutun öğrenme süreçlerine dahil edilmesiyle mevcut öğretim teknikleri de gelişmektedir (Perdomo, Shiratuddin, Thabet \& Ananth, 2005). Örneğin, Scalfani ve Vaid (2014) tarafindan yürütülen bir çalışmada, moleküler yapıların çeşitli dijital 3D yapıları hazırlanmıştır. Araştırma sonuçları doğrultusunda, bu yapılarla simetri ve nokta gruplarının öğretiminin daha kolay olacağı belirtilmiştir. McCollum, Regier, Leong, Simpson ve Sterner (2014) tarafindan lisans öğrencileri ile yürütülen bir başka çalışmada ise iPad kullanılarak 3D molekül yapıları hazırlanmıştır. Araştırmacıların elde ettiği sonuçlara göre 3D molekül yapılarıyla çalışan öğrencilerin, çalışma kâğıtlarıyla çalışan öğrencilere göre daha yüksek kavramsal yetkinlik gösterdikleri tespit edilmiştir. Bununla birlikte, bu uygulamaların literatürde yapılan farklı çalışmalarda orbital ve blok kopolimer nanoyapı gibi çeşitli konuların öğretimi için de faydalı olduğu belirtilmektedir (Lolur \& Dawes, 2014; Robertson \& Jorgensen, 2015; Scalfani, Turner, Rupar \& Jenkins, 2015).

Ayrıca böyle uygulamaların, fen dersleri kapsamında sunulan ve doğayı ve doğal olayları açıklayan olgu, kavram, ilke, yasa ve kuramların daha anlaşılır olması için görsel öğretim zenginliği sağlanabileceği ifade edilmektedir (Çepni, 2010). Tinkercad yazılımı da bu görselliği sağlamak adına fen sınıflarında kullanılabilecek dijital tasarımların oluşturulması için tasarlanmış eğlenceli, kullanımı kolay ve web tabanlı bir 3D uygulamasıdır. Daha karmaşı modelleme tekniklerine geçmeden önce 3D tasarımla ilgili aşamaların anlaşılması ve bunlara yönelik nesneler tasarlanması amacıyla kullanılacak bir eğitsel araç olarak tanımlanabilir. Tinkercad programı, tarayıcı tabanlı çalıştığı için bilgisayara kurulum yapmaya gerek duyulmadan internet üzerinden uygulama yapılmasını sağlayan kullanışlı bir araçtır. Bu ortam, tasarım yapmak ve hayal gücünün ürünlerini ortaya koymak için hayatın her kesiminden öğrencilere, bireylere ve üreticilere kolaylık sağlayan platform olarak da ifade edilmektedir. Yazılım ile tasarlanan şekil ve nesneler üç boyutlu yazıcılar ile de somut materyallere dönüşebilmektedir (Griffey, 2014). Bununla birlikte, Tinkercad programına erişim ücretsizdir ve söz konusu program Türkçe dil desteği sunmaktadır. Tinkercad ile 3D tasarım oluşturmanın yanı sıra programlama uygulamaları kapsamında kodlama çalışmaları da yapılabilmektedir. Bu noktada, kod blokları ile blok tabanlı kodlama imkanının sunulması ile birlikte C++ ile kodlama deneyimi yaşanmasını da sağlamaktadır. Bu bağlamda, çok amaçlı kullanım firsatları sunan ve kolay erişime sahip olan bu programa ilişkin farkındalığın artırılmasının eğitimciler için faydalı olabileceği düşünülmektedir.

$\mathrm{Bu}$ bakış açısından hareketle bu çalışmanın amacı; 3D uygulama imkânı sunan Tinkercad programının fen bilgisi öğretmen adaylarına tanıtılması, öğretmen adaylarının söz konusu programı kullanarak uygulamalar yapmasının sağlanması ve programın fen derslerinde kullanılabilirliğine ilişkin görüşlerinin tespit edilmesi şeklinde belirlenmiştir. 


\section{YÖNTEM}

\section{Araştırmanın Modeli}

$\mathrm{Bu}$ çalışmada, nitel araştırma yöntemlerinden durum araştırması deseni kullanılmıştır. Bu desen çeşitli veri kaynaklarının kullanılması ile bir durumun anlaşılmasına olanak sağlamaktadır (Baxter \& Jack, 2008). Bu sosyal durumun doğası durum araştırmalarında çeşitlilik göstermektedir. Örneğin, söz konusu durum bir kurum, bir rol ya da rol yapma, bir şehir ve bir grup birey olabilir (Feagin, Orum \& Sjoberg, 1991). Bu araştırmada ise öğretmen adaylarından oluşan bir grup çalışmanın durumunu oluşturmaktadır. Ayrıca bir durum araştırmasında, durum kavramı ve durumun ne olduğunu incelemek önem taşımaktadır. Durum kavramı, sınırlandırılmış bir içerikte meydana gelen olgu şeklinde tanımlanmakta ve aslında analiz öğesi olarak ifade edilmektedir (Miles \& Huberman, 1994). Bu bağlamda, çalışmanın durumu, öğretmen adaylarının 3D dijital program olan Tinkercad hakkındaki görüşlerini tespit etmek olarak belirlenmiştir. Söz konusu durum 1şığında, bu çalışmanın durum araştırması türlerinden araçsal (enstrümantal) durum araştırması çerçevesinde olduğu ifade edilebilir. Araçsal durum çalışmaları, bir konunun örneklendirilmesi amacıyla incelemeye alınan durum ya da durumlara yönelik belirli bir meselenin aydınlatılması için söz konusu meselenin odak noktasını değerlendirmektedir (Creswell, 2012). Bu çalışmada, günümüzde oldukça popüler ve çok çeşitli olan öğretim teknolojileri konusu için örnek olarak 3D teknolojilerini içeren Tinkercad programı seçilmiş ve programın öğretim süreçlerinde kullanılmasındaki odak noktalardan biri şeklinde ifade edilebilecek geleceğin öğretmenleri olan günümüzün öğretmen adaylarının görüşlerinin irdelenmesi amaçlanmıştır. Nitekim, eğitsel ortamlara teknoloji entegrasyonunun sağlanabilmesi için öğretmen ve öğretmene ilişkin özelliklerin önemi sıklıkla vurgulanmaktadır (Albion, 1996; Bingimlas, 2009; Cennamo, Ross \& Ertmer, 2010; Ertmer, 1999; Ertmer \& Ottenbreit-Leftwich, 2010; Fullan \& Stiegelbauer, 1991; Korte \& Hüsing, 2006; Newhouse, 2002; Osborne \& Hennessy, 2003; Pelgrum, 2001; Sicilia, 2006).

\section{Çalışma Grubu/ Evren- Örneklem}

$\mathrm{Bu}$ araştırmanın çalışma grubunu bir devlet üniversitesinin Fen Bilgisi Eğitimi Anabilim Dalında 2016-2017 eğitim öğretim yılı bahar döneminde öğrenim gören gönüllü 40 fen bilgisi öğretmen aday1 oluşturmaktadır. Söz konusu katılımcıların Tinkercad ya da benzeri bir 3D modelleme programına yönelik deneyimleri bulunmamaktadır. Bununla birlikte, öğretmen adaylarının hiçbiri daha önce benzer bir eğitim programına katılmamıştır. Araştırma bulgularının sunumu esnasında katılımcıların gizliliğini korumak adına her bir öğretmen adayı "Ön” (örneğin $\ddot{O}_{1}, \ddot{O}_{2}$ gibi) şeklinde kodlanmıştır.

\section{Veri Toplama Aracı}

Araştırmanın veri toplama araçları öğretmen adayları tarafından hazırlanan dokümanlar ve yarıyapılandırılmış görüşme formu olarak belirlenmiştir.

\section{Doküman İncelemesi}

Nitel araştırmacıların bir çalışmadaki bölge ya da katılımcılar hakkında edindikleri yerel ya da özel kayıtları kapsayan kaynaklar doküman olarak adlandırılmaktadır (Creswell, 2012). Nitel araştırmalar için önemli bilgi kaynakları olan dokümanlar gazeteleri, toplantı tutanaklarını, bireysel günlükleri ve mektupları içerebilir (Cohen, Manion \& Morrison, 2007).

$\mathrm{Bu}$ çalışmada, her bir öğretmen adayından Tinkercad programının fen derslerinde kullanımına yönelik görüşlerini açıklayan bir metin yazmaları istenmiştir. Bu doküman, birincil kaynak niteliğindeki yazı dokümanı olarak ifade edilmektedir (Cohen, Manion \& Morrison, 2007). Yazılması istenen metnin ana fikri hakkında öğretmen adaylarına açıklama yapılmış ve Tinkercad programının öğrenme ortamlarına sunacağı olası etkilere ilişkin görüşlerine odaklanmaları belirtilmiştir.

\section{Görüşme Formu}

$\mathrm{Bu}$ çalışmada, 3 adet açık uçlu sorudan oluşturulan yarı-yapılandırılmış görüşme formu kullanılmıştır. Araştırmada açık uçlu soruların kullanılmasının en önemli nedeni, bu tür soruların hem araştırmacıya üzerinde çalıştığı konuyla ilgili esnek bir yaklaşım olanağı sunması hem de incelenen konuyla ilgili önemli değişkenlerin gözden kaçmasını önlemesi (Yıldırım \& Şimşek, 2005) olarak ifade edilebilir. 
Çalışma kapsamındaki görüşme soruları, araştırmanın amacı ile ilgili yeterli veri elde etmek için dikkatlice hazırlanmıştır. Bu aşamada, üç alan eğitimi uzmanı soruları inceleyerek görüş ve önerilerini belirtmişlerdir. Alınan uzman görüşleri doğrultusunda sorular düzenlenmiş ve görüşme formunun son hali verilmiştir.

Görüşme süreci rastgele seçilen 10 öğretmen adayı ile aynı araştırmacı tarafindan yürütülmüştür. Sürecin başlangıcında, her bir öğretmen adayından yapılacak görüşmenin ses kayıt cihazı ile kaydedilmesi hususunda izin alınmıştır. Görüşmelerin tamamlanması ile tüm kayıtlar kodlanmış ve görüşmeler transkript edilerek metin haline getirilmiştir. Görüşmeler esnasında takip edilen aşamalar ve form kapsamındaki sorular Tablo 1'de sunulmaktadir.

Tablo 1.

Görüşme süreci rehberi

\begin{tabular}{lll}
\hline Görüşme Aşaması & Yönergeler & Süre \\
\hline Giriş & Görüşmenin amacı hakkında bilgi sunma & $5-6 \mathrm{dk}$. \\
& $\begin{array}{l}\text { Görüşmenin gizliliği hakkında açılama yapma } \\
\text { Ses kaydı izni talep etme }\end{array}$ & \\
\hline Görüşme Soruları & Tinkercad programını öğrenme sürecinde zorlandınız mı? & 25-30 dk. \\
& Tinkercad programı uygulamalarının sizce olumlu ve olumsuz & \\
& yönleri nelerdir? Lütfen, cevaplarınızın nedenlerini açıklayınız. & \\
& Tinkercad programını gelecekteki meslek hayatınızda \\
& kullanmayı düşünüyor musunuz? & \\
\hline
\end{tabular}

\section{Verilerin Toplanması ve Analizi}

$\mathrm{Bu}$ çalışmada, 3D dijital tasarım hazırlanması amacıyla Autodesk firması tarafından geliştirilmiş Tinkercad programı kullanılmıştır. Tinkercad tarayıcı tabanlı çalışan bir 3D tasarım ve modelleme aracı olarak ifade edilmektedir (Tinkercad, 2018). 3D uygulama yapılması amacıyla bu programın seçilmesinin temel nedenleri Tinkercad tarafından sunulan Türkçe dil seçeneği ve uygulamanın ücretsiz olması şeklinde ifade edilebilir. Uygulama sürecinde, çeşitli moleküllerin değerlik-kabuk elektron-çifti itme (VSEPR) kuramı yardımıyla 3D uygulamaları yapılmıştır (Lewis, 1916; Gillespie, 1992; Gillespie \& Hargittai, 2013). Çalışma kapsamında bu konunun seçilme nedeni ise soyut kavramların daha karmaşık ve güç süreçler aracılığıyla öğrenilmesinden (Canpolat, Pınarbaşı, Bayrakçeken \& Geban, 2004) dolayı moleküllerin geometrik yapılarının somut olarak açıklanmasının öğrenme süreci açısından avantajlı olabileceğinin düşünülmesi (Scalfani \& Vaid, 2014) olarak açıklanabilir. Eğitim programı kapsamında gerekli olan materyallerin listesi Tablo 2'de sunulmaktadır.

Tablo 2 .

Materyal listesi

\begin{tabular}{ll}
\hline Materyal & Adet \\
\hline İnternet bağlantısı bulunan bilgisayar* & Her bir öğrenci için 1 adet \\
VSEPR Modeli çalışma yaprağı & Her bir öğrenci için 1 adet \\
Program broşürü & Her bir grup için 1 adet \\
\hline
\end{tabular}

*Alternatif olarak, öğrenciler dizüstü bilgisayar kullanabilir.

Eğitim programında öncelikle Tinkercad programı araştırmacılar tarafından tanıtılmış ve programın kullanımı hakkında bilgi verilmiştir. Bu süreçte, öğretmen adayları Tinkercad programının kullanımına yönelik eğitime bireysel olarak katılmıştır. Eğitim programının başlangıcında Tinkercad programının özellikleri ve menüleri tanıtılmış ve ardından hareket ettirme, ölçek ayarı yapma, gruplama, grup çözme, delik oluşturma, eksen belirleme ve klavye kısa yolları gibi gerekli bilgiler verilmiştir.

Eğitim programı süreci, haftada ikişer saatlik birer oturum kapsamında 7 haftada tamamlanmıştır. Tasarım süreci boyunca, öğretmen adayları gruplar halinde işbirlikçi olarak çalışmıştır. Süreç boyunca araştırmacılar, öğretmen adaylarına dönütler vererek program kullanımı konusunda yardımcı olmuştur. Eğitim programına ve sürece ilişkin zaman çizelgesi Tablo 3'te sunulmaktadır. 
Tablo 3.

Tinkercad eğitim programı içeriği

\begin{tabular}{|c|c|}
\hline Hafta & Aktivite \\
\hline 1 & $\begin{array}{l}\text { 3D tasarım ortamının tanıtılması } \\
\text { İlk hafta gerçekleştirilen bu etkinlikte öğretmen adaylarına Tinkercad 3D tasarım ortamı tanıtılmıştır. } \\
\text { Tasarım sürecinde çoğunlukla kullanılan araçlar, parçaları gruplama ve bu grupları çözme, tasarımın } \\
\text { ayrılmış parçalarını birbirine hizalama, boşluk oluşturma, eksenlerde döndürme gibi özellikler örnekler } \\
\text { eşliğinde tanıtılmıştır. }\end{array}$ \\
\hline 2 & $\begin{array}{l}\text { Örnek genel uygulama: Bir bardak tasarlama } \\
\text { İkinci hafta gerçekleştirilen bu etkinlikte, öğretmen adaylarının programı kullanarak bir bardak tasarımı } \\
\text { yapmaları sağlanmıştır. Bu tasarımda, sensör yerleştirilecek yuvalar da bulunmaktadır. Bu etkinliğin } \\
\text { tamamlanmasının ardından, öğretmen adaylarından bir sonraki oturum için tamamıyla kendi tasarımları } \\
\text { olan özgün birer bardak tasarlamaları istenmiştir. Bir örnek Şekil } 1 \text {. de verilmiştir. }\end{array}$ \\
\hline 3 & $\begin{array}{l}\text { Fen bilimleri uygulaması hazırlık } \\
\text { Bu aşamada, öğretmen adaylarından dörder kişilik gruplar oluşturulmuştur. Oturum kapsamında, } \\
\text { VSEPR Kuramı hakkında genel bilgiler verilmiş ve çeşitli moleküllerin geometrik yapılarının örnekleri } \\
\text { sunulmuştur. Ardından, her bir grup Tinkercad Programı ile oluşturacağı molekül geometrik yapısını } \\
\text { belirlemiştir. }\end{array}$ \\
\hline 4 & $\begin{array}{l}\text { Fen bilimleri uygulaması } \\
\text { Bu oturumda, öğretmen adayları seçtikleri moleküllerin Tinkercad aracıllı̆̆ıla geometrik yapılarını } \\
\text { oluşturmuşlardır. Araştırmacılar, bu süreçte gruplara rehberlik ederek onları yönlendirmiştir. VSEPR } \\
\text { kuramı yardımılya moleküllerin geometrik yapılarının uygulamalarına odaklanan bu oturumda, her bir } \\
\text { öğretmen adayına dağıtılan çalışma yapraklarındaki moleküllerin geometrik yapıları üzerinden tartışma } \\
\text { sürecine devam edilmiştir. Çalışma yapraklarının içeriği ile ilgili iki örnek Tablo } 4 \text { ve Tablo } 5 \text { de } \\
\text { verilmiştir }\end{array}$ \\
\hline 5 & $\begin{array}{l}\text { Gruplar tamamladıkları moleküllerin geometrik yapılarını sınıfta sunmuş ve öğretmen adayları, diğer } \\
\text { grupların çalışmaları hakkında yorum yapmaya teşvik edilmiştir. Gelen öneriler değerlendirilmiştir. }\end{array}$ \\
\hline 6 & $\begin{array}{l}\text { Gruplar, tamamladıkları moleküllerin geometrik yapılarını son değerlendirmelerden sonra oturum } \\
\text { kapsamında sınıfta tekrar sunmuştur. Grupların moleküllerin geometrilerinde revize etmeleri gereken } \\
\text { bölümler belirlenmiştir. }\end{array}$ \\
\hline 7 & $\begin{array}{l}\text { Her bir grup, gelen öneriler doğrultusunda yapmış olduğu düzenlemeleri bu oturum kapsamında } \\
\text { paylaşmıştır. Her bir öğretmen adayı Tinkercad programın uygulanabilirliği hakkındaki görüşlerini } \\
\text { açıkladıkları birer metin yazmıştır. }\end{array}$ \\
\hline
\end{tabular}

Tablo 4.

Su için geometrik yapı

\begin{tabular}{|c|c|c|c|c|c|}
\hline \multirow[b]{2}{*}{ Örnek } & \multirow[b]{2}{*}{ Toplam } & \multicolumn{2}{|c|}{ Elektron çifti sayısı } & \multirow[b]{2}{*}{ Çizimle gösterim } & \multirow[b]{2}{*}{ Geometrik yap1 } \\
\hline & & Bağlayıcı & $\begin{array}{c}\text { Bağlayıcı } \\
\text { olmayan }\end{array}$ & & \\
\hline $\mathrm{H}_{2} \mathrm{O}$ & 4 & 2 & 2 & $\begin{array}{c}\mathrm{O}-\mathrm{H} \\
\mathrm{I} \\
\mathrm{H}\end{array}$ & Açısal \\
\hline
\end{tabular}


Tablo 5 .

Metan için geometrik yapı

\begin{tabular}{|c|c|c|c|c|c|}
\hline \multirow[b]{2}{*}{ Örnek } & \multirow[b]{2}{*}{ Toplam } & \multicolumn{2}{|c|}{ Elektron çifti sayısı } & \multirow[b]{2}{*}{ Çizimle gösterim } & \multirow[b]{2}{*}{ Geometrik yap1 } \\
\hline & & Bağlayıcı & $\begin{array}{c}\text { Bağlayıcı } \\
\text { olmayan }\end{array}$ & & \\
\hline $\mathrm{CH}_{4}$ & 4 & 4 & 0 & $\begin{array}{c}\mathrm{H} \\
\mathrm{I} \\
\mathrm{H}-\mathrm{C}-\mathrm{H} \\
\mathrm{I} \\
\mathrm{H}\end{array}$ & Düzgün dört yüzlü \\
\hline
\end{tabular}

Araştırma verileri, nitel verilerin analiz süreçlerinde en çok ve yaygın bir şekilde kullanılan analiz türü şeklinde ifade edilen içerik analizi yöntemi (Özdemir, 2010; Büyüköztürk, Çakmak, Akgün, Karadeniz \& Demirel, 2009) kullanılarak değerlendirilmiştir. İçerik analizi yöntemi, metin içeriğindeki konuyu açıklarken kullanılan durumların tekrarlanan ifadelerini ele alan ve söz konusu ifadeler aracılı̆̆ıyla geçerli çıkarımlarda bulunmayı sağlayan bir teknik olarak ifade edilmektedir (Krippendorff, 2004). Bu çalışmada, öğretmen adaylarının eğitim programı ve Tinkercad uygulaması hakkındaki görüşlerini incelemek amacıyla görüşme dökümleri ve dokümanlar incelenmiştir. Bu aşamada, benzer ifadeler aynı kod ve temalar altında toplanmıştır. Verilerin kodlanması sürecinde Creswell (2012) tarafından ifade edilen aşamalar takip edilmiştir: (1) Birçok sayfadan oluşan veri metni okunur; (2) metin içeriği doğrultusunda bölümlere ayrılır; (3) elde edilen bilgi bölümleri ortak ifadeler kapsamında kodlarla etiketlenir; (4) çakışan ve gereksiz kodlar tespit edilerek azaltılır; (5) oluşturulan kodlar barındırdıkları ana fikir doğrultusunda temalara yerleştirilir.

\section{BULGULAR}

40 fen bilgisi öğretmen adayıyla gerçekleştirilen Tinkercad programı uygulamalarına yönelik 7 haftalık eğitim programı sonunda, öğretmen adayları gruplar halinde çalışarak çeşitli moleküllerin VSEPR kuramı yardımıyla 3D uygulamalarını tamamlamışlardır. Adayların gruplarıyla birlikte Tinkercad Programını kullanarak yapmış oldukları bazı moleküllere ait $\left(\mathrm{CH}_{4}, \mathrm{NH}_{3}, \mathrm{H}_{2} \mathrm{O}, \mathrm{SF}_{6}\right)$ örnek görüntüler Şekil $1-5$ 'te verilmiştir. Uygulama sürecinin tamamlanması ile öğretmen adaylarının sürece ait görüşlerini değerlendirmek amaciyla, dokümanlar ve transkriptlerden elde edilen veriler incelenmiş ve değerlendirilmiştir.

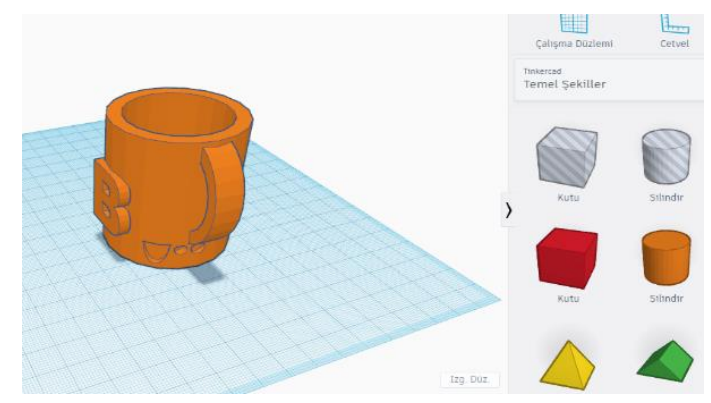

Şekil 1. Bardak tasarımı örneği 


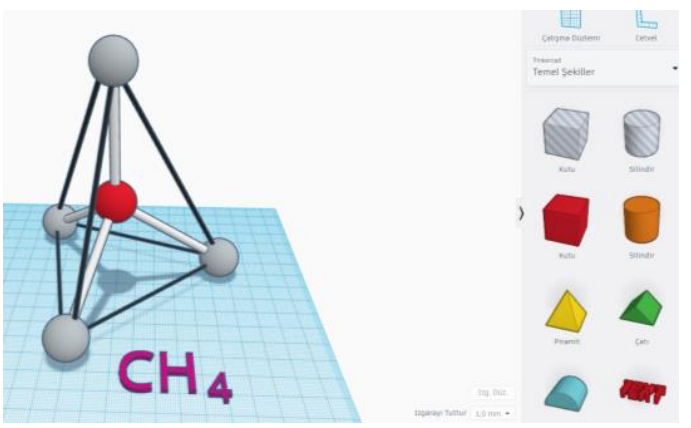

Şekil 2. $\mathrm{CH}_{4}$ (metan)

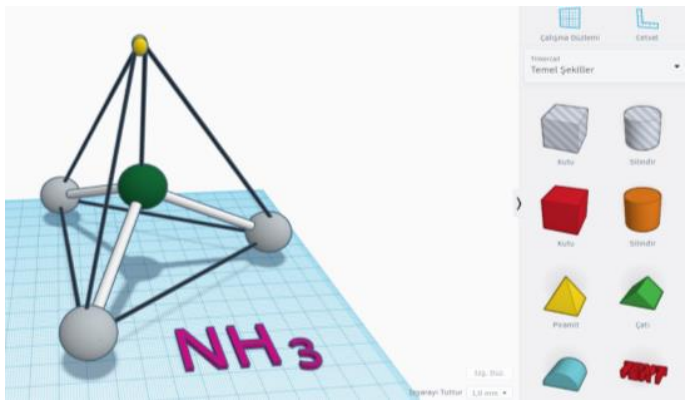

Şekil 3. $\mathrm{NH}_{3}$ (amonyak)

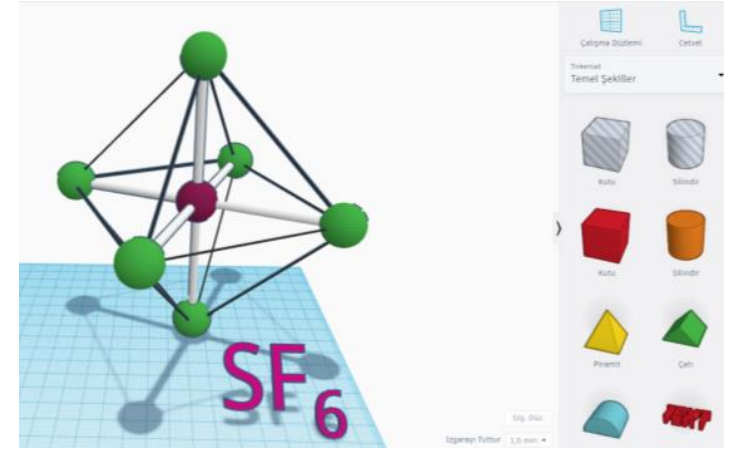

Şekil 4. $\mathrm{SF}_{6}$ (kükürt hekzaflorür)

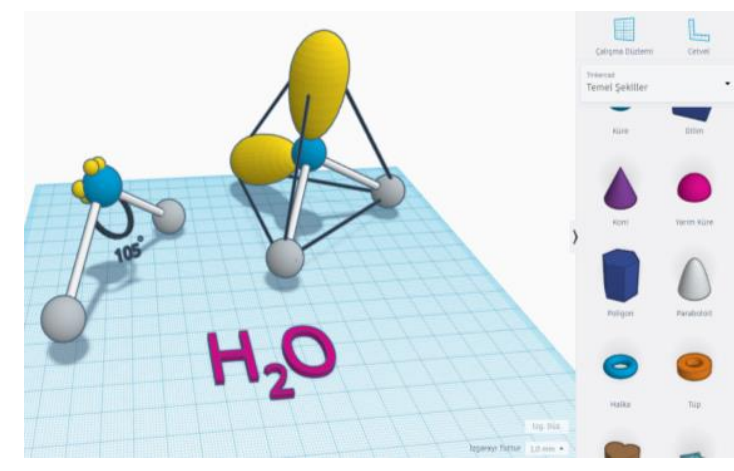

Şekil 5. $\mathrm{H}_{2} \mathrm{O}(\mathrm{su})$

\section{Doküman İncelemesine İlişkin Bulgular}

Eğitim programı uygulama sürecine katılan 40 fen bilgisi öğretmen adayı ile yürütülen uygulamalar sonucunda adaylar Tinkercad programının fen öğretiminde kullanılabilirliğine ilişkin düşüncelerini ifade ettikleri metinleri yazmışlardır. Elde edilen metinler içerik analizi yöntemi kapsamında incelenmiştir. Açıklanan görüşlerin "Eğitsel Etkiler" ve "Uygulanabilirlik" olmak üzere iki temada toplandığı görülmüştür. "Eğitsel Etkiler" kategorisi altında yer alan görüşlerin ana fikirleri kişisel gelişim, öğrenme ve ilgi çerçevesinde şekillenmiştir. "Uygulanabilirlik" teması kapsamında yer alan yanıtların sınıf ortamı ve ders planı ana fikirleri üzerine yoğunlaştığı görülmüş̧ür. Analiz süreci sonucunda oluşturulan tema ve kodlar Tablo 6'da sunulmaktadır.

Tablo 6.

Öğretmen adaylarının Tinkercad'in fen derslerinde uygulanabilirliğine ilişkin görüşleri

\begin{tabular}{llc}
\hline Temalar & Kodlar & $\mathrm{n}$ \\
\hline & Yaratıcılık & 30 \\
& Hayal gücü & 7 \\
& Görsel okuma & 5 \\
& Üç boyutlu düşünme & 7 \\
& Üretkenlik & 3 \\
Eğitsel Etkiler & Kalı̈ı ögrenme & 27 \\
& Somutlaştırma & 21 \\
& Kolay öğrenme & 16 \\
& Pekiştirme & 7 \\
& Eğlenceli & 5 \\
& Motivasyon & 28 \\
& Merak & 19 \\
& Pozitif ilgi & 8 \\
\hline
\end{tabular}


Tablo 6 incelendiğinde, fen bilgisi öğretmen adaylarının genel olarak Tinkercad programı ve uygulamalarına yönelik olumlu eğilim gösterdikleri ifade edilebilir. Örneğin, adayların çoğunluğu Tinkercad aracılı̆̆ıyla öğrencilerin yaratıcılıklarının gelişeceğini belirtmiştir. 7 öğretmen adayı programın öğrencilerin hayal gücünü geliştirileceğini, 5'i görsel okuma becerilerine katkı sağlayacağını ve 7 aday ise üç boyutlu düşünme becerilerinin gelişimini destekleyeceğini ifade etmiştir. Öğretmen adayları Tinkercad programının öğrenme üzerinde etkili olacağı yönünde açıklamalar da yapmışlardır. Örneğin, adayların 27'si bu programın entegre edildiği konular aracilığıyla kalıcı öğrenmenin gerçekleşebileceğini ve 21 aday ise soyut kalan benzer fen konularının somutlaştırılabileceğini belirtmiştir. Özelikle fen bilimleri kapsamında öğrencilere soyut gelen DNA yapısı ve atom gibi konuların öğretiminde programın kullanımının önemini vurgulamıştır. Bunun yanı sıra, öğretmen adayları Tinkercad uygulamaları ile yapılan etkinlerin öğrencilerin fene olan ilgileri üzerinde olumlu etkileri olabileceğini ifade etmişlerdir. Örneğin, 28 öğretmen adayı bu uygulamaları içeren öğretim süreçleri ile öğrencilerin motivasyonlarının da artacağını belirtmiştir.

Ayrıca, öğretmen adaylarının Tinkercad programının uygulanabilirliği hakkında yaptıkları yorumlar incelendiğinde, adaylar bu aktivitelerin öğrencileri derse teşvik ederek aktif katılımı artıracağ interaktif bir ortamda öğrenmelerin gerçekleşebileceğini vurgulamışlardır $(\mathrm{n}=23)$. Buna ek olarak, 20 öğretmen adayı bu program ile oluşturulan ders planlarının etkili olacağını ifade etmişlerdir. Bununla birlikte bazı öğretmen adayları ise $(n=4)$ programın ders planları ile bütünleştirilmesinin ders süresi bakımından fazla zaman gerektirebileceğini de ifade etmişlerdir.

Öğretmen adaylarının görüşlerini belirttikleri metinlerden örnekler kesitler halinde aşağıda sunulmaktadir.

Ö 27 'nin görüşü aşağıda verilmiştir:

“...Bence Tinkercad ile hazırladığım program motivasyon açısından çok olumluydu. Ayrıca 3D yazıcılardan çıkmış materyaller öğrencileri derse motive eder. Öğrenme açısından da somutlaştırdığ için öğrenmeyi kolaylaştııı. Öğrencilerin yaratıcılıklarının gelişımine de katkılar sağlayacağını düşünüyorum..."

$\ddot{O}_{32}$ 'nin görüşü aşağıdaki gibidir:

“...Öğreticiliği konusunda gayet etkili, kalıcı, başarılı olacağını düşünüyorum. Strateji olarak buluş ve araştırma-inceleme stratejisi kullanılarak öğrenci daha aktif hale getirilebilir. Teknik olarak da öğrenciyi daha aktif hale getirmek için yine aynı şekilde beyin firtınası gibi teknikler kullanılarak kalıcılık ve öğrenme artırılabilir. Değerlendirme aşamasında öğrencilerden de benzer bir tasarım istenebilir böylece yaratıcılıkları ortaya çıkar ve geliştirilmiş olur. Derse giriş sırasında da dikkat çekici olarak modeller kullanılırsa motivasyon arttırılarak öğrenciler güdülenmiş olur..."

Ö${ }_{13}$ 'ün görüşü aşağıda verilmiştir:

“...Öğrenciler açısından dikkat çekici olacağına inanıyorum. Aynı zamanda mesleki rehberlik açısından da böyle programların yönlendirici olabileceğine, tasarım konusunda yetenekli olan öğrencileri ayırt edebileceğine inanıyorum. Fen dersi açısından da öğrencileri aktifleştirip bilgi kalıcılığını arttıracağına inanıyorum. Böylece yaratıcıkları gelişerek öğrenmeleri pekişir..."

Ö 19 'un görüşü ise şu şekildedir:

“...Bu program Fen bilimleri dersinde birçok konuda kullanılabilir. Atom ve yapısı öğretilirken özellikle kullanılmalıdır. Fen bilimleri soyut kavramlar içerdiğinden bu şekilde soyut kavramları gözle görülür hale getirebiliriz. Ayrıca öğrencinin merak ve ilgisi artar ve öğrenci böylece derse karşı da olumlu tutum kazanabilir..."

$\ddot{O}_{21}$ 'in görüşü ise şu şekildedir:

“...Biyoloji uygulamalarında da kullanılabilir. Örneğin bitkiler de çiçeğin yapısı konusunda kolaylıkla uygulanabilir..."

Ö${ }_{11}^{\prime}$ in görüşü ise şu şekildedir:

“...Öğretici bir program. Fen bilimleri dersinde fizik uygulamaları yapılabilir. Örneğin basit makinalar konusunun anlaşılması için katkılar sağlayacağını düşünüyorum...”

$\mathrm{O}_{22}$ 'nin görüşü ise şu şekildedir: 
“...Biyoloji uygulamalarında özellikle DNA'nın üç boyutlu yapısını program aracılığıyla daha öğretici hale getirebiliriz..."

\section{Görüşme Formuna İlişkin Bulgular}

Görüşme süreci, katılımcıların tamamı arasından rastgele seçilen 10 öğretmen adayı ile yürütülmüştür. Yarı-yapılandırılmış görüşme formunda yer alan her bir soruya verilen yanıtlara ilişkin analiz sonuçları sırasıyla bu bölümde açılanmaktadır.

Soru 1: Tinkercad programını öğrenme sürecinde zorlandınız mı?

5 öğretmen adayı, katıldıkları eğitim programı sürecinde Tinkercad kullanımını öğrenerek 3D uygulamalar tasarlama noktasında zorlanmadıklarını belirtmiştir. Bununla birlikte, öğretmen adaylarının 2'si programı kullanma sırasında zaman zaman zorluk yaşadıklarını ifade ederken, 3 öğretmen adayı programın kullanımını öğrenme noktasında oldukça zorlandıklarını açıklamışlardır.

Ö${ }_{1}^{\prime}$ 'in Tinkercad programını öğrenme sürecine ilişkin görüşü şu şsekildedir:

“...Genel olarak zorlanmadım. Ama başlangıçta çok önyargılıydım çünkü teknolojiyle aram çok iyi olmadığı için. Ama uygulama yaptıktan sonra bana çok eğlenceli geldi. Diğer etkinliklerde yardım almadan kendim yapabildim..."

$\ddot{O}_{29}$ 'un Tinkercad programını öğrenme sürecine ilişkin görüşü ise aşağıda verilmiştir:

“...̇̇lk defa bir 3D uygulama ve tasarım programını öğrendiğim için biraz zorlandım. Fakat benim için çok zevkliydi..."

Soru 2: Tinkercad programı uygulamalarının sizce olumlu ve olumsuz yönleri nelerdir? Lütfen, cevaplarınızın nedenlerini açıklayınız.

$\mathrm{Bu}$ soruya verilen yanıtlar, olumlu ve olumsuz yönler temaları altında toplanmış ve Tablo 7'de sunulmuştur.

Tablo 7.

Öğretmen adayların Tinkercad uygulamaları hakkındaki olumlu ve olumsuz görüşleri

\begin{tabular}{lll}
\hline Temalar & Kodlar & $\mathrm{n}$ \\
\hline & Kolaylık & 7 \\
& Eğlenceli & 6 \\
\multirow{2}{*}{ Olumlu Yönler } & Kişisel tasarım & 4 \\
& Türkçe dil & 4 \\
& Hazır şekil & 3 \\
& 3D çktı & 1 \\
\hline \multirow{2}{*}{ Olumsuz Yönler } & Sinırlı şekil & 2 \\
& Yerleştirme & 2 \\
\hline
\end{tabular}

Öğretmen adaylarının Tinkercad programına ilişkin programın olumlu yönlerini açıklarken genel olarak kolay kullanıma sahip olduğunu belirttikleri görülmüştür. 7 katılımcının uygulama arayüzünün kolay kullanım imkânı sunduğunu ifade ettiği dikkat çekmektedir. Ayrıca, öğretmen adayları programın hayal ettikleri tasarımları gerçeğe dönüştürme ve Türkçe dil imkânı sunma özelliklerine de değinmiştir. Tinkercad programına yönelik olumsuz görüşler incelendiğinde, 2 öğretmen adayının uygulama tarafından sunulan şekillerin sınırlılığ herhangi bir olumsuz yanı olmadığını ifade etmiştir. Bu soruya verilen katılımcı cevaplarına ilişkin örnekler aşağıda sunulmaktadır.

Ö6'nın Tinkercad hakkındaki görüşü şu şekildedir:

“...Tinkercad uygulamalarını genel olarak beğendim. Çünkü okulda öğrencilere 3 boyutlu yönleri gösterme ve düşündürme açısından faydalı olduğunu düşünüyorum. Konuları somutlaştırma açısından da faydalı olduğunu düşünüyorum. Materyal eksikliği yaşandığında da konulara (özellikle fen konularını) somutlaştırmak açısından oldukça kullanışlı bir program..."

Ö 14 'ün görüşü aşağıda verilmiştir:

“...Tinkercad programının en beğendiğim yönü programda yapılan üç boyutlu tasarımların çıktısının alınabiliyor olmasıydı. Hayal edip oluşturduğumuz şekiller çıktı olarak alınabiliyordu. Aynı zamanda bu ürünlere sensör vb. yerleştirebiliyorduk..."

$\ddot{O}_{38}$ 'in tasarım programının beğenmediği yönlerine ilişkin görüşü aşağıda verilmiştir: 
“...Programın beğenmediğim yönü ise tasarımda kullanabileceğim her türlü şekil ve parçanın programda bulunmaması idi. Bu açıdan sınırlıydı..."

Soru 3: Tinkercad programını gelecekteki meslek hayatınızda kullanmayı düşünüyor musunuz?

Öğretmen adaylarının bu soruya verdikleri yanıtlar incelendiğinde, genel olarak her birinin mesleki yaşantılarında Tinkercad programını kullanmada istekli oldukları görülmüştür. Yalnızca bir öğretmen adayı, 3D uygulama ve tasarım yapmanın zaman alıcı olduğunu ve bu nedenle çok sık kullanabileceğini düşünmediğini ifade etmiştir. Bunun dışında, tüm öğretmen adayları programın fen öğretiminde soyut kavramları somutlaştırmada ve anlamlı öğrenme açısından son derece önemli olduğunu belirtmişlerdir. Gelecekteki kendi sınıflarında Tinkercad programına kesinlikle yer vereceklerini özellikle ders planlarına entegre edeceklerini vurgulamışlardır.

\section{TARTIŞMA, SONUÇ ve ÖNERILER}

Bu çalışma 40 fen bilgisi öğretmen adayı ile yürütülmüştür. Araştırma kapsamında 3D uygulama programlarından biri olan Tinkercad programı öğretmen adaylarına tanıtılmış ve moleküllerin geometrik yapıları üzerine uygulamalar yapılmıştır. Öğretmen adayları, uygulama sürecinde çeşitli moleküllerin geometrik yapılarını VSEPR kuramına göre 3D olarak hazırlamışlardır. 7 haftalık bir eğitim süreci sonunda öğretmen adaylarından program hakkında ve programın fen bilimlerinde kullanımına yönelik görüşleri alınmıştır.

Çalışmada, durum araştırması deseni kullanılmıştır. Araştırmanın veri toplama araçları; öğretmen adayları tarafından yazılan dokümanlar ve 3 sorudan oluşan yarı-yapılandırılmış görüşme formu olarak belirlenmiştir. Elde edilen nitel veriler içerik analizi yöntemi ile değerlendirilmiştir.

Öğretmen adaylarının yazmış olduğu dokümanların incelenmesi sonucunda adayların Tinkercad programına karşı genel olarak olumlu görüşlere sahip oldukları görülmüştür. Bu bağlamda, adayların programın fen sınıflarında öğretim aracı olarak uygulanabilirliğine odaklandıkları ortaya çıkmıştır. Nitekim, ilgili literatür incelendiğinde öğretmenlerin eğitim-öğretim ortamlarında öğrenmenin kalitesini arttırmak için farklı teknolojik destekler almasının ve eğitsel hedeflere ulaşılması noktasında teknolojinin sınıf içi uygulamalar için özelleştirilebilmesinin öneminin vurgulandığı görülmektedir (Koehler vd, 2011).

Adaylar programın özellikle öğrenme üzerindeki etkilerine değinmiş ve Tinkercad'in kalıcı ögrenme sağlayacağı ve fen bilimlerinde soyut kavramların somutlaştırılması gibi noktalarda öğrencileri destekleyeceğini belirtmişlerdir. Fen öğretiminde, öğrencilerde anlamlı öğrenmelerin gerçekleşmesi için öğretim sürecinde öğrencilerin kendi bilgilerini kullanarak yeni bilgiler oluşturmalarına ve uygulamalar yapmalarına fırsat sağlanması son derece önemlidir. Öğrenme ortamlarında yapılan uygulamalarda ögrencilerin özellikle zihinsel olarak kendilerinin katılımının önemli olduğu ve bu tip uygulamaların etkili bir öğrenme için etkili olduğu da literatürde belirtilmektedir (Daşdemir, \& Doymuş, 2016).

Öğretmen adayları Tinkercad programı uygulamalarının fen öğretimi için uygun olduğunu belirtirken ayrıca Tinkercad ile desteklenmiş eğitsel ortamlar aracılığıyla, öğrencilerin merak, yaratıcılık ve hayal gücü gibi becerilerin de gelişeceğini ve bu şekilde, sınıf ortamında öğrencilerin derse teşvik edilmesiyle aktif katılımın artıracağını ifade etmişlerdir. Benzer şekilde literatürde araştırmacılar da bu tür teknolojilerin öğrencilerde ilgi ve merak uyandıracağını ve motivasyonlarını geliştireceğini vurgulamaktadır (Cradler, J., McNabb, M., Freeman, M., \& Burchett, R. 2002).

Doküman inceleme sürecinin ardından yarı-yapılandırılmış görüşme formundan elde edilen veriler analiz edilmiştir. Daha önce programla ilgili bilgileri olmadığını belirten öğretmen adaylarına ilk olarak katıldıkları eğitim programı kapsamında Tinkercad öğrenmenin zorluk derecesine ilişkin görüşme sorusu yöneltilmiştir. Bu soruya verilen cevaplar incelendiğinde, öğretmen adaylarının genel olarak programı öğrenme sürecinde zorluk yaşamadıkları sonucuna ulaşılmıştır. Bu nedenle düzenlenen eğitim programının Tinkercad öğretimi ve uygulaması için yeterli olduğu ifade edilebilir.

Öğretmen adaylarının Tinkercad programının olumlu ve olumsuz yönlerine ilişkin görüşlerini tespit etmek amacıyla hazırlanan görüşme sorularına verdikleri cevaplar incelendiğinde de çoğu öğretmen adayının program hakkında herhangi bir olumsuz görüşe sahip olmadığı görülmüştür. Bununla birlikte, öğretmen adayları Tinkercad tarafından sunulan kolay kullanım imkânı, eğlenceli aktivite imkânı ve kişisel tasarım yapma imkânı gibi avantajlara değinerek program hakkındaki olumlu görüşlerini açıklamışlardır. 
Öğretmen adaylarının bu çalışma kapsamında belirtmiş oldukları 3D uygulamalarla ilgili olumlu görüşlere benzer görüşler de literatürde vurgulanmaktadır. Nitekim öğrenciler, modelleme aracılığıyla fen konularına ilişkin daha geniş kapsamlı bir kavrayış geliştirme eğilimi göstermektedirler (Louca \& Zacharia, 2012). 3D uygulamalarıyla öğrenme öğrencileri fikir üreten, kanıt toplayan ve elde edilen kanıtları gözlemledikleri olguyu açıklamak için kullanan bireylere dönüştürmekte ve bu sayede hem öğrencilerin derse katılımını sağlamakta hem de öğrencilerin önemli becerilerini geliştirmektedir (Kolonich, 2017). Ayrıca, bazı adaylar uygulamanın sınırlı şekil sunmasını ve düzlem üzerinde cisimleri yerleştirme noktasında yaşadıkları sorunları da bildirmişlerdir $(n=6)$.

Öğretmen adayları genel olarak uygulama sürecinden sonra, bu programın fen derslerinde kullanılmasının öğrencilerin farklı öğrenme alanlarına hitap edeceğini de vurgulamışlardır. Öğreten açısından da bu durumun önemli olduğunu ve programı derslerinde kullanacaklarını söylemişlerdir. Nitekim öğretim ortamları ile teknolojinin bütünleştirilmesi aracıllğıyla öğrencilerin daha kolay, daha hızlı, daha kalıcı ve daha etkili öğrenmelerinin sağlanması ile birlikte öğretmenlerin de iş doyumuna ulaşacakları literatürde ifade edilmektedir (Ozan, 2009).

Programı kullanma noktasında emin olamayan öğretmen adayı ise dijital tasarım yapmanın zaman alıcı olduğunu belirtmiş ve programla uygulamaya ayıracak zamanı bulma konusunda sıkıntılar yaşanabileceğini çünkü sınıflarda öğretim programlarını yetiştirememe durumunun olabileceğini ifade etmiştir. Belirtilen bu görüşün nedenleri arasında teknoloji entegrasyonuna engel olan faktörler arasında görülen deneyim eksikliğinin (Abbott \& Faris, 2000; Bingimlas, 2009; Ertmer, 1999; Ertmer \& Ottenbreit-Leftwich, 2010) neden olduğu düşünülmektedir. Nitekim öğretmen adayları daha önce bu tip uygulamaları veya herhangi bir yazılım ya da araç kullanmadıklarını ifade etmiş̧lerdir.

$\mathrm{Bu}$ araştırmanın sonuçları, öğretmen adaylarına eğitim süreçleri boyunca derslerinde teknoloji entegrasyonuna yönelik daha fazla deneyim yaşayabilecekleri firsatların sunulması gerekliliğini ortaya çıkarmış ve ayrıca sınıf ortamlarında kullanılabilecek böyle uygulamaların ders planlarına nasıl entegre edebileceğini araştıran yeni çalışmalara da ihtiyaç olduğunu düşündürmektedir.

\section{KAYNAKÇA}

Abbott, J. A., \& Faris, S. E. (2000). Integrating technology into preservice literacy instructions a survey of elementary education students' attitudes toward computers. Journal of Research on Computing in Education, 33(2), 149-161.

Albion, P. R. (1996). Student-teachers' use of computers during teaching practice in primary classrooms. Asia-Pacific Journal of Teacher Education, 24(1), 63-73

Baxter, P., \& Jack, S. (2008). Qualitative case study methodology: Study design and implementation for novice researchers. The qualitative report, 13(4), 544-559.

Bingimlas, K. A. (2009). Barriers to the successful integration of ICT in teaching and learning environments: A review of the literature. Eurasia Journal of Mathematics, Science \& Technology Education, 5(3), 235-245.

Büyüköztürk, SS., Çakmak, E. K., Akgün, Ö. E., Karadeniz, Ş., \& Demirel, F. (2009). Bilimsel araştırma yöntemleri. Ankara: Pegem Akademi.

Canpolat, N., Pınarbaşı, T., Bayrakçeken, S., \& Geban, Ö. (2004). Kimyadaki bazı yaygın yanlış kavramalar. Gazi Üniversitesi Gazi Eğitim Fakültesi Dergisi, 24(1).

Cennamo, K., Ross, J., \& Ertmer, P. (2009). Technology integration for meaningful classroom use: A standards-based approach. California: Wadsworth, Cengage Learning.

Cohen, L., Manion, L., \& Morrison, K. (2007). Research methods in education. New York: Routledge.

Copolo, C. E., \& Hounshell, P. B. (1995). Using three-dimensional models to teach molecular structures in high school chemistry. Journal of science education and technology, 4(4), 295-305.

Cradler, J., McNabb, M., Freeman, M., \& Burchett, R. (2002). How does technology influence student learning?. Learning and Leading with Technology, 29(8), 46-49.

Creswell, J. W. (2012). Educational research: Planning, conducting, and evaluating quantitative and qualitative research. Boston, MA: Pearson Education. 
Çepni, S. (2010). Kuramdan Uygulamaya Fen ve Teknoloji Öğretimi. Pegem Akademi Yayınc1lı: Ankara.

Drummond, A., \& Sweeney, T. (2017). Can an objective measure of technological pedagogical content knowledge (TPACK) supplement existing TPACK measures?. British Journal of Educational Technology, 48(4), 928-939.

Daşdemir, İ., \& Doymuş, K. (2016). Maddenin yapısı ve özellikleri ünitesinde animasyon kullanımının öğrencilerin akademik başarılarına, hatırda tutma düzeyine ve bilimsel süreç becerilerine etkisi. Bayburt Ĕ̈itim Fakültesi Dergisi, 8(1), 84-101.

Ertmer, P. A. (1999). Addressing first-and second-order barriers to change: Strategies for technology integration. Educational Technology Research and Development, 47(4), 47-61.

Ertmer, P. A., \& Ottenbreit-Leftwich, A. T. (2010). Teacher technology change: How knowledge, confidence, beliefs, and culture intersect. Journal of Research on Technology in Education, 42(3), 255-284.

Feagin, J. R., Orum, A. M., \& Sjoberg, G. (Eds.). (1991). A case for the case study. UNC Press Books.

Fullan, M., \& Stiegelbauer, S. (1991). The new meaning of educational change. New York: Teachers College.

Gillespie, R. J. (1992). Electron densities and the VSEPR model of molecular geometry. Canadian Journal of Chemistry, 70(3), 742-750.

Gillespie, R. J., \& Hargittai, I. (2013). The VSEPR model of molecular geometry. Courier Corporation.

Griffey, J. (2014). The types of 3-D printing. Library Technology Reports, 50(5), 8-12.

Han, I., Eom, M., \& Shin, W. S. (2013). Multimedia case-based learning to enhance pre-service teachers' knowledge integration for teaching with technologies. Teaching and Teacher Education, 34, 122-129.

Kaberman, Z., \& Dori, Y. J. (2009). Question posing, inquiry, and modeling skills of chemistry students in the case-based computerized laboratory environment. International Journal of Science and Mathematics Education, 7(3), 597-625.

Kolonich, A. (2017). Supporting Urban Secondary Science Teachers in Promoting Equitable Science Classrooms Through Inclusive Three-Dimensional Instruction. Doctoral dissertation, Michigan State University.

Koehler, M. J., Mishra, P., Bouck, E. C., DeSchryver, M., Kereluik, K., Shin, T. S., \& Wolf, L. G. (2011). Deep-play: Developing TPACK for 21st century teachers. International Journal of Learning Technology, 6(2), 146-163.

Korte, W. B., \& Hüsing, T. (2006). Benchmarking access and use of ICT in European schools 2006: Results from head teacher and a classroom teacher surveys in 27 European countries. Retrieved from http://www.awt.be/contenu/tel/dem/final_report_3.pdf

Krippendorff, K. (2004). Content analysis: An introduction to its methodology. Thousand Oaks, CA: Sage.

Lazarowitz, R., \& Naim, R. (2013). Learning the cell structures with three-dimensional models: Students' achievement by methods, type of school and questions' cognitive level. Journal of Science Education and Technology, 22(4), 500-508.

Lewis, G. N. (1916). The atom and the molecule. Journal of the American Chemical Society, 38(4), 762-785.

Lolur, P. \& Dawes, R. (2014). 3D printing of molecular potential energy surface models. Journal of Chemical Education, 91(8), 1181-1184.

Louca, L. T., \& Zacharia, Z. C. (2012). Modeling-based learning in science education: cognitive, metacognitive, social, material and epistemological contributions. Educational Review, 64(4), 471-492.

Matzen, N. J., \& Edmunds, J. A. (2007). Technology as a catalyst for change: The role of professional development. Journal of Research on Technology in Education, 39(4), 417-430. 
McCollum, B. M., Regier, L., Leong, J., Simpson, S., \& Sterner, S. (2014). The effects of using touchscreen devices on students' molecular visualization and representational competence skills. Journal of Chemical Education, 91(11), 1810-1817.

Miles, M. B., \& Huberman, A. M. (1994). Qualitative data analysis: An expanded sourcebook. sage.

Newhouse, P. (2002). Literature review: The impact of ICT on learning and teaching. Perth: Western Australian Department of Education, 32(3), 16-22.

Noeth, R. J., \& Volkov, B. B. (2004). Evaluating the effectiveness of technology in our schools. (ACT Policy Report). Retrieved from http://files.eric.ed.gov/fulltext/ED483855.pdf.

Osborne, J., \& Hennessy, S. (2003). Literature review in science education and the role of ICT: Promise, problems and future directions (A NESTA Futurelab Research Report No. 06). Retrieved from https://telearn.archives-ouvertes.fr/hal-00190441/.

Ozan, C. (2009). Illköğretim Sinı Öğretmenlerinin Eğitim Teknolojileri Açısından Yeterlilikleri (Erzurum İli Örneği). Yayınlanmamış Yüksek Lisans Tezi, Atatürk Üniversitesi, Sosyal Bilimler Enstitüsü, Erzurum.

Özdemir, M. (2010). Nitel veri analizi: Sosyal bilimlerde yöntembilim sorunsalı üzerine bir çalışma. Eskişehir Osmangazi Üniversitesi Sosyal Bilimler Dergisi, 11(1), 323-343.

Pelgrum, W. J. (2001). Obstacles to the integration of ICT in education: Results from a worldwide educational assessment. Computers \& Education, 37(2), 163-178.

Perdomo, J. L., Shiratuddin, M. F., Thabet, W., \& Ananth, A. (2005). Interactive 3D visualization as a tool for construction education. In 2005 6th International Conference on Information Technology Based Higher Education and Training (pp. F4B-23). IEEE.

Robertson, M. J. \& Jorgensen, W. L. (2015). Illustrating concepts in physical organic chemistry with 3D printed orbitals. Journal of Chemical Education, 92(12), 2113-2116.

Scalfani, V. F., Turner, C. H., Rupar, P. A., Jenkins, A. H. \& Bara, J. E. (2015). 3D Printed Block Copolymer Nanostructures. Journal of Chemical Education, 92(11), 1866-1870.

Scalfani, V. F. \& Vaid, T. P. (2014). 3D printed molecules and extended solid models for teaching symmetry and point groups. Journal of Chemical Education, 91(8), 1174-1180.

Schwarz, C. V., Reiser, B. J., Davis, E. A., Kenyon, L., Achér, A., Fortus, D., Shwartz, Y., Hug, B., \& Krajcik, J. (2009). Developing a learning progression for scientific modeling: Making scientific modeling accessible and meaningful for learners. Journal of Research in Science Teaching: The Official Journal of the National Association for Research in Science Teaching, 46(6), 632-654.

Sicilia, C. (2006). The challenges and benefits to teachers' practices in constructivist learning environments supported by technology (Master's Thesis). Retrieved from https://www.learntechlib.org/p/126851/.

Smiar, K., \& Mendez, J. D. (2016). Creating and using interactive, 3D-printed models to improve student comprehension of the bohr model of the atom, bond polarity, and hybridization. Journal of Chemical Education, 93(9), 1591-1594.

Stieff, M., Hegarty, M., \& Deslongchamps, G. (2011). Identifying representational competence with multi-representational displays. Cognition and Instruction, 29(1), 123-145.

Stieff, M., Ryu, M., Dixon, B., \& Hegarty, M. (2012). The role of spatial ability and strategy preference for spatial problem solving in organic chemistry. Journal of Chemical Education, 89(7), 854859 .

Tinkercad (2018). https://www.tinkercad.com/about/features (Erişim Tarihi:18/03/2018).

Yarema, R., Deptuch, G., Hoff, J., Shenai, A., Trimpl, M., Zimmerman, T., Demarteau, M., Lipton, R., \& Christian, D. (2010). 3D design activities at Fermilab - Opportunities for physics. Nuclear Instruments and Methods in Physics Research Section A: Accelerators, Spectrometers, Detectors and Associated Equipment, 617(1-3), 375-377.

Yıldırım, A. \& Şimşek, H. (2005). Sosyal Bilimlerde Nitel Araştırma Yöntemleri. Ankara. Seçkin Yayıncilik. 
Zheng, J., Birktoft, J. J., Chen, Y., Wang, T., Sha, R., Constantinou, P. E., Ginell, L., Mao, C., \& Seeman, N. C. (2009). From molecular to macroscopic via the rational design of a self-assembled 3D DNA crystal. Nature, 461(7260), 74. 